\title{
Concrete-Filled Double Skin Steel Tubular Columns Exposed to ASTM E-119 Fire Curve for 60 and 90 Minutes of Fire
}

\author{
Sharifah Salwa Mohd Zuki ${ }^{1,2}$, Shahiron Shahidan ${ }^{2,}$, Choong Kok Keong, \\ $J$. Jayaprakash ${ }^{3}$, and Noorwirdawati $\mathrm{Ali}^{2}$ \\ ${ }^{l}$ School Civil Engineering, Universiti Sains Malaysia, Nibung Tebal 14300 Pulau Pinang, \\ Malaysia \\ ${ }^{2}$ Jamilus Research Center, Faculty of Civil and Environmental Engineering, Universiti Tun \\ Hussein Onn Malaysia, 86400 Batu Pahat, Johor, Malaysia \\ ${ }^{3}$ Department of Civil Engineering, The University of Notthingham, Malaysia Campus, \\ Semenyih, Selangor, Malaysia
}

\begin{abstract}
Concrete-filled double skin steel tubular (CFDST) columns with outer steel tubes varying in diameter and thickness were exposed to ASTM E-119 fire curve for 60 and 90 minutes. All specimens (control and heated) failed by outward local buckling of outer steel tube, crushing of concrete and outward and inward buckling of inner steel tube. Residual Strength Index (RSI), secant stiffness and Ductility Index (DI) were calculated in order to compare the performance of control and fire-damaged CFDST columns. It was found that specimens with 90 minutes of fire exposure time possessed highest RSI. Meanwhile, secant stiffness seems to decrease with increased exposure time. And finally, CFDST columns became more ductile after being heated.
\end{abstract}

\section{Introduction}

In the event of fire, fire safety is first addressed by sprinklers or smoke detectors which are part of the active fire protection system. However, if the fire becomes larger and this so-called active fire protection system failed to suppress the fire, the passive fire protection system will then take over. The passive fire protection system exists in order to ensure the integrity of the structures for a period of time so that the occupant can safely evacuate the building or until the arrival of fire fighters. The integrity of the structures can be achieved by providing adequate cover to

*Corresponding author: shahiron@uthm.edu.my 
reinforcement, adequate fire protection layers, compartmentalization and etc [1-4]. In addition, the structures also need to prevent the fire from spreading and collapsing during fire [2].

There are many known advantages of concrete-filled double skin steel tubular (CFDST) columns over traditional reinforced concrete (RC) columns and concretefilled steel tubular (CFST) columns in literature. Among them are; 1) higher fire resistance to fire even without fire protection layer on outer steel tube, 2) higher load bearing capacity, 3) prevent the spalling of concrete, 4) eliminate the need for formwork, 5) increase the strength, ductility and energy absorption and 6) reduced column footing [3-9]. However, the usage of CFDST columns is limited to outdoor construction such as transmission towers [7], and bridge piers [8-10] even though the performance of CFDST column is superior to RC and CFST columns. To date, research studies on CFDST columns exposed to fire are limited and can be found in previous research [9-16]. As for the residual strength of CFDST columns after fire, none can be found in the literature. Residual strength of fire-damaged columns is important so that it can be used to assess the damage done by fire. Therefore, engineers can calculate the amount of repair that needs to be done[16-19].

In this study, CFDST columns are subjected to ASTM E-119 fire curve for two different exposure periods, i.e., 60 and 90 minutes. In addition, the diameter and thickness of the outer steel tubes of CFDST columns are varied. The Residual Strength Index, Secant Stiffness and Ductility Index of fire-damaged CFDST columns are calculated and compared with unheated CFDST columns.

\section{Experimental program}

\subsection{Preparation of specimens and material properties}

A total of 54 specimens were casted in an upright position as shown in Fig. 1(a). Details of the specimens together with the tensile stress of steel and compressive strength of concrete are presented in Table 1. The overall length of each specimen is $600 \mathrm{~mm}$ and for each S1 (represent Series 1 which indicates the outer steel tube diameter of the specimen) there are two different outer steel tube thicknesses, which are $3 \mathrm{~mm}$ (represent by $\mathrm{C} 3$ ) and $4 \mathrm{~mm}(\mathrm{C} 4)$ respectively. In addition, the notations 'control', '60' and '90' at the end of the specimen naming convention indicate the un-heated specimen and the specimen heated to 60 and 90 minutes of exposure time, respectively.

The targeted strength of concrete is $30 \mathrm{~N} / \mathrm{mm}^{2}$. For every batch of specimens, six $100 \times 100 \times 100 \mathrm{~mm}$ cubes were casted and cured in a concrete laboratory (aircured). Specimens and cubes were cured in similar conditions until the day of the test for specimens and after 7 and 28 days for the cubes. Three steel coupons were cut from the outer and inner steel tube and tested in order to determine its properties. Both concrete strength after 28 days and tensile stress of outer and inner steel tubes are listed in Table 1. Concrete cubes and steel coupons were tested in accordance with BS EN 12390-3 [20] and ASTM E8/E8M-11 [21] respectively. 


\subsection{Heating regime}

The specimens were heated in a gas-fired fire furnace at the concrete laboratory in Universiti Sains Malaysia (USM). The specimens were heated one at a time as shown in Fig.1(b). The specimens were heated in accordance with ASTM E-119 [22] fire curve until the temperature reached $600^{\circ} \mathrm{C}$. The temperature is kept constant for 60 and 90 minutes. After it has reached the targeted exposure time, the furnace will automatically turn off and the lid of the furnace is lifted. The specimens were left to cool down inside the furnace before being taken out of the furnace to completely cool down to room temperature as shown in Fig. 1(c).

The temperature of the furnace for the entire exposure time is measured by four ceramic thermocouples attached to the furnace wall. The temperature of the concrete and inner steel tubes during the heating process is measured by thermocouples. The thermocouple for concrete is inserted during the casting process. Meanwhile, the thermocouple for the inner steel tube is attached to the wall of the tube before the heating process commences. The thermocouple used is thermocouple type $\mathrm{K}$ with a length of $1000 \mathrm{~mm}$ and a diameter of $3 \mathrm{~mm}$. At the end of the thermocouple, there is a $1000 \mathrm{~mm}$ cable that can be attached to a data logger in order to record temperature during the heating process.

\subsection{Axial compression test}

All specimens were subjected to monotonic axial compression load using a Universal Testing Machine (UTM) with a maximum load capacity of $2000 \mathrm{kN}$ until failure at the Construction Research Institute of Malaysia (CREAM), Kuala Lumpur. Each specimen was equipped with four $10 \mathrm{~mm}$ electrical strain gauges located at the mid-height of the specimens. Two strain gauges were placed in horizontal direction, whereas another two were placed in hoop direction. In addition, four Linear Variable Displacement Transducers (LVDTs) were placed at the mid-height of the specimens. During testing, axial load and axial displacement were recorded using UTM. The test arrangement is shown in Fig. 2.

Table 1. Details of tested specimens.

\begin{tabular}{|l|c|c|c|c|c|c|}
\hline Specimens & $\begin{array}{c}\text { Dia. of } \\
\text { outer } \\
\text { steel } \\
\text { tube } \\
{[\mathrm{mm}]}\end{array}$ & $\begin{array}{c}\text { Dia. } \\
\text { of } \\
\text { inner } \\
\text { steel } \\
\text { tube } \\
{[\mathrm{mm}]}\end{array}$ & $\begin{array}{c}\text { Compressiv } \\
\text { e strength } \\
\text { of concrete } \\
\text { after 28 } \\
\text { days } \\
{\left[\mathrm{N} / \mathrm{mm}^{2}\right]}\end{array}$ & $\begin{array}{c}\text { Tensile stress } \\
\text { of outer steel } \\
\text { tube } \\
{\left[\mathrm{N} / \mathrm{mm}^{2}\right]}\end{array}$ & $\begin{array}{c}\text { Tensile } \\
\text { stress of } \\
\text { inner steel } \\
\text { tube } \\
{\left[\mathrm{N} / \mathrm{mm}^{2}\right]}\end{array}$ & $\begin{array}{c}\text { Exposur } \\
\text { e time } \\
{[\mathrm{min}]}\end{array}$ \\
\hline $\begin{array}{l}\text { S1-C3- } \\
\text { Control }\end{array}$ & 101.6 & 50.8 & 38 & 597 & 762 & - \\
\hline S1-C3-60 & 101.6 & 50.8 & 38 & 597 & 762 & 60 \\
\hline S1-C3-90 & 101.6 & 50.8 & 38 & 597 & 762 & 90 \\
\hline $\begin{array}{l}\text { S1-C4- } \\
\text { Control }\end{array}$ & 101.6 & 50.8 & 39 & 561 & 762 & - \\
\hline S1-C4-60 & 101.6 & 50.8 & 39 & 561 & 762 & 60 \\
\hline S1-C4-90 & 101.6 & 50.8 & 39 & 561 & 762 & 90 \\
\hline $\begin{array}{l}\text { S2-C3- } \\
\text { Control }\end{array}$ & 127.0 & 76.2 & 41 & 436 & 449 & - \\
\hline S2-C3-60 & 127.0 & 76.2 & 40 & 436 & 449 & 60 \\
\hline
\end{tabular}




\begin{tabular}{|l|c|c|c|c|c|c|}
\hline S2-C3-90 & 127.0 & 76.2 & 40 & 436 & 449 & 90 \\
\hline $\begin{array}{l}\text { S2-C4- } \\
\text { Control }\end{array}$ & 127.0 & 76.2 & 43 & 449 & 449 & - \\
\hline S2-C4-60 & 127.0 & 76.2 & 42 & 449 & 449 & 60 \\
\hline S2-C4-90 & 127.0 & 76.2 & 38 & 449 & 449 & 90 \\
\hline $\begin{array}{l}\text { S3-C3- } \\
\text { Control }\end{array}$ & 152.4 & 101.6 & 40 & 409 & 566 & - \\
\hline S3-C3-60 & 152.4 & 101.6 & 40 & 409 & 566 & 60 \\
\hline S3-C3-90 & 152.4 & 101.6 & 41 & 409 & 566 & 90 \\
\hline $\begin{array}{l}\text { S3-C4- } \\
\text { Control }\end{array}$ & 152.4 & 101.6 & 40 & 430 & 566 & - \\
\hline S3-C4-60 & 152.4 & 101.6 & 42 & 430 & 566 & 60 \\
\hline S3-C4-90 & 152.4 & 101.6 & 38 & 430 & 566 & 90 \\
\hline
\end{tabular}

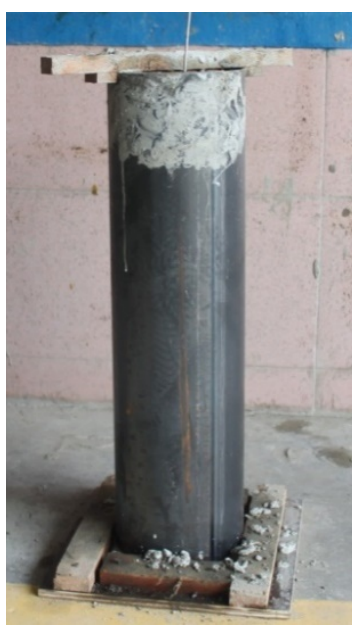

(a)

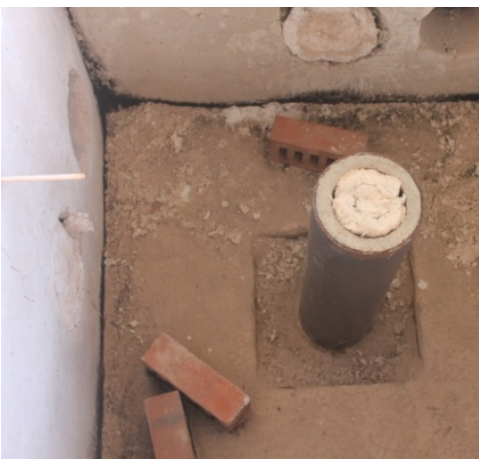

(b)

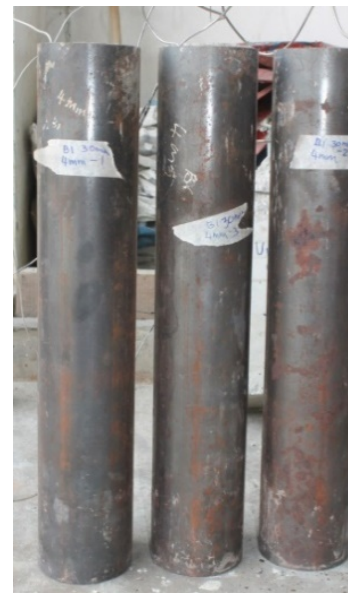

(c)

Fig. 1. (a) CFDST columns after casting process; (b) CFDST columns during heating process; (c) CFDST columns after cooling process.

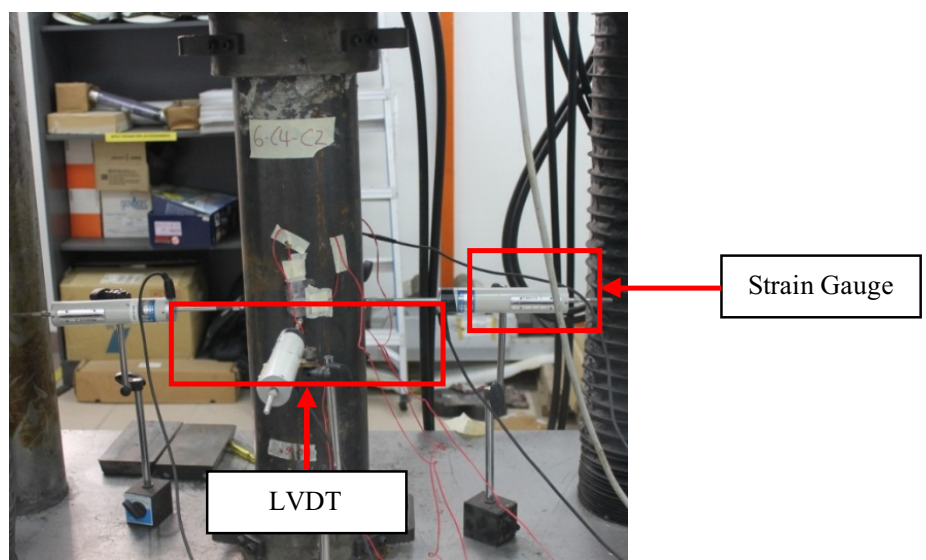

Fig. 2. Test arrangement. 
During the curing process, a small amount of shrinkage occurred at the top of the specimens. The gap was filled with high strength epoxy. The epoxy was left overnight to harden. Once hardened, the surface was ground smooth with a grinding wheel for even distribution of stress during the testing process.

\section{Result and discussion}

\subsection{Overall behavior}

As seen in Fig. 1(a) and Fig. 1(c), there are no changes in physical appearance of the specimens before and after being exposed to fire. However, the concrete inside CFDST columns changed significantly as shown in Fig. 3. The concrete changed from its normal color to whitish grey. This indicates that the temperature within the concrete has already exceeded $300^{\circ} \mathrm{C}$. Researchers often associate a temperature of $300^{\circ} \mathrm{C}$ as an indicator where concrete starts to lose its strength [23]. Nevertheless, the concrete was still intact due to the outer and inner steel tube, preventing the occurrence of spalling in concrete. However, for specimens exposed to 90 minutes of fire, the resulting concrete was brittle and crumbled under very small pressure as shown in Fig. 3(c). A detailed discussion can be found in [24-26].

All specimens failed by outward local buckling of the outer steel tube, crushing of concrete and outward and inward local buckling of inner steel tube. Outward local buckling of outer steel tube, crushing of concrete and outward and inward local buckling of inner steel tube can be seen in Fig. 3, Fig. 4 and Fig. 5 respectively.

The occurrence of outward local buckling in outer steel tube was due to the presence of concrete that prevented the steel from buckling in an inward direction. As for the inner steel tube, the failure pattern resembles the failure of hollow steel tubes. In addition, the position of local buckling for both outer and inner steel tube corresponded to the position where the crushing of concrete occurs. It was also observed that a longer exposure time leads to more severe buckling and crushing of steel and concrete. Therefore, it can be concluded that a longer exposure time significantly affects the strength of CFDST columns.

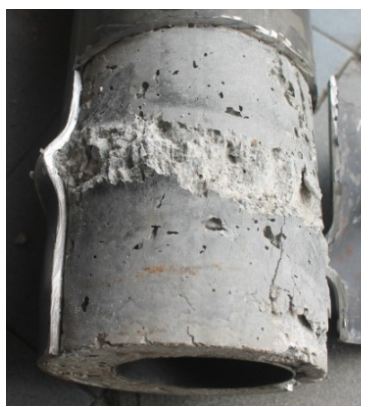

(a)

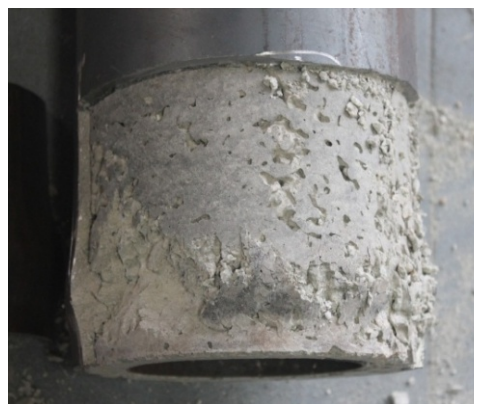

(b)

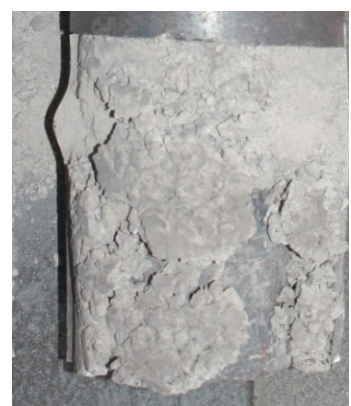

(c)

Fig. 3. Condition of concrete (a) control specimen; (b) 60 minutes of fire exposure; (c) 90 minutes of fire exposure. 


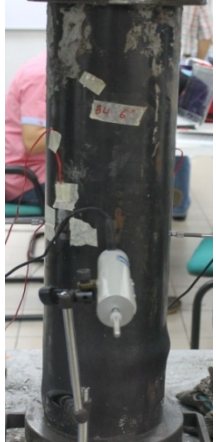

(a)

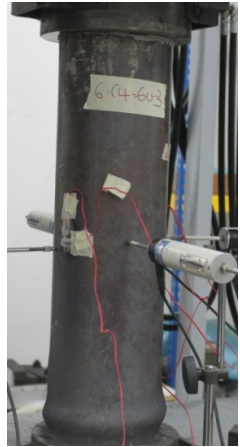

(b)

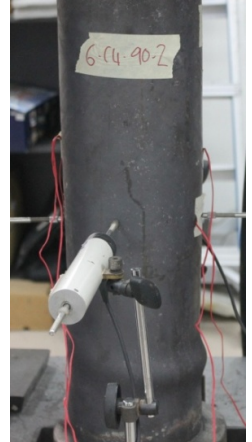

(c)

Fig. 4. CFDST columns after axial compression test (a) control; (b) 60 minutes of fire exposure; (c) 90 minutes of fire exposure.

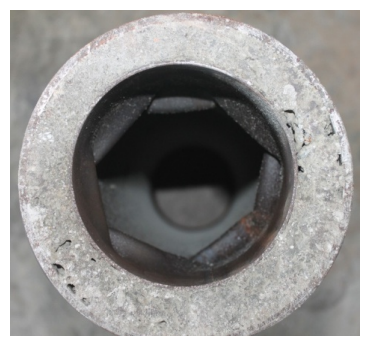

(a)

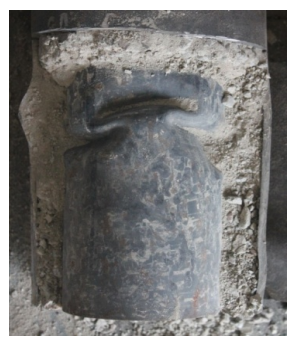

(b)

Fig. 5. Failure pattern of inner steel tube (a) top view; (b) side view.

\subsection{Residual Strength Index, Secant Stiffness and Ductility Index}

Residual Strength Index, RSI is calculated using an equation suggested by Han \&Huo [27]. A higher value of RSI means that the damage done by fire is more severe compared to a low value of RSI. Therefore, zero in control specimens means that there is no damage observed among the specimens. The average values of the three specimens in terms of RSI, secant stiffness and Ductility Index, DI are presented in Table 2 .

RSI for 60 and 90 minutes of exposure time is shown in Fig. 6. The RSI for 90 minutes of exposure time is higher than 60 minutes exposure time for both outer tube thicknesses, $\mathrm{t}_{0}$, i.e., $3 \mathrm{~mm}$ and $4 \mathrm{~mm}$. Higher RSI can be attributed to a longer exposure time. Specimens with a longer exposure time absorb more heat thus increasing the maximum temperature attained by the outer steel tube, concrete and inner steel tube. If the inner steel tube is well protected, the maximum temperature attained will be lower thus it is able to retain its load carrying capacity. As mentioned earlier, the temperature distribution of CFDST columns is discussed in [24-26].

In addition, the specimen with $\mathrm{t}_{0}=3 \mathrm{~mm}$ is found to have a higher RSI than the specimen with $\mathrm{t}_{0}=4 \mathrm{~mm}$. This applies for both 60 and 90 minutes of exposure time. This is because a thicker $t_{0}$ slows down the process of heat transfer from steel to concrete. This lowered the maximum temperature attained by concrete and the 
inner steel tube thereby lowering the RSI value.

From Fig. 6(b), it is interesting to note that the RSI value for S1-C4-60 is negative. The negative value means that the fire-damaged CFDST column in these series gained strength instead of losing its strength after fire exposure. This is the result of a thicker $\mathrm{t}_{0}$ when compared to S1-C3-60 (RSI $\left.=13 \%\right)$. According to Gunalan \& Mahendran (2014)[28, low grade steel loses its strength at a slower rate compared to high grade steel. In addition, yield strength of the steel remains unaffected until it reaches a temperature of around 500 to $600^{\circ} \mathrm{C}[29,30]$. With other parameters (exposure time, length, diameter and steel grade) being constant, it can therefore be concluded that specimens with $\mathrm{t}_{0}=4 \mathrm{~mm}$ retain more strength than its counterparts thus obtaining a negative value of RSI.

Secant stiffness is calculated by dividing ultimate compressive load with displacement at an ultimate compressive load. Secant stiffness decreases with increased exposure time regardless of $\mathrm{t}_{0}$. The specimen with 60 minutes of exposure time loses secant stiffness ranging from 11\% (S3-C4-60) to 51\% (S1-C4-60 and S2C4-60) from original secant stiffness (Fig. 7). As for the specimen exposed to 90 minutes of exposure time, secant stiffness as high as 64\% (S1-C4-90) to as low as $36 \%$ (S3-C4-90) is lost. Similar to RSI, a longer exposure time leads to more heat absorption thus resulting in a high reduction in terms of secant stiffness.

The Ductility Index, DI was calculated using an equation suggested by [31]. DI for Series 1 decreases with increased exposure time regardless of $t_{0}$. However, for Series 2 and Series 3, DI increases as exposure time increases (Fig. 8). Interestingly, DI for Series 2 and Series 3 for specimens with $\mathrm{t}_{0}=4 \mathrm{~mm}$ exceeded the original DI. This means that the specimens became more ductile after fire exposure. Other researchers like Tao et al. (2008) [32] and Tao \& Han (2007) [33]also found out that the ductility of CFST columns after fire exposure increases. This can be attributed to changes in the properties of steel and concrete after being exposed to high temperature.

Table 2. Test results of tested specimens.

\begin{tabular}{|l|c|c|c|}
\hline \multicolumn{1}{|c|}{ Specimens } & $\begin{array}{c}\text { Residual Strength Index } \\
{[\%]}\end{array}$ & $\begin{array}{c}\text { Secant Stiffness } \\
{[\mathrm{kN} / \mathrm{mm}]}\end{array}$ & $\begin{array}{c}\text { Ductility Index, } \\
\text { DI }\end{array}$ \\
\hline S1-C3-Control & 0 & 32 & 1.08 \\
\hline S1-C3-60 & 13 & 49 & 1.47 \\
\hline S1-C3-90 & 16 & 38 & 1.23 \\
\hline S2-C3-Control & 0 & 142 & 1.86 \\
\hline S2-C3-60 & 4 & 101 & 1.35 \\
\hline S2-C3-90 & 10 & 84 & 1.41 \\
\hline S3-C3-Control & 0 & 251 & 1.40 \\
\hline S3-C3-60 & 15 & 131 & 1.31 \\
\hline S3-C3-90 & 22 & 102 & 1.26 \\
\hline S1-C4-Control & 0 & 108 & 2.02 \\
\hline S1-C4-60 & -2 & 53 & 1.63 \\
\hline S1-C4-90 & 5 & 39 & 1.40 \\
\hline S2-C4-Control & 0 & 228 & 2.04 \\
\hline S2-C4-60 & 16 & 111 & 1.70 \\
\hline S2-C4-90 & 16 & 105 & 2.37 \\
\hline S3-C4-Control & 0 & 201 & 1.49 \\
\hline S3-C4-60 & 8 & 179 & 1.56 \\
\hline S3-C4-90 & 15 & 129 & 1.80 \\
\hline
\end{tabular}




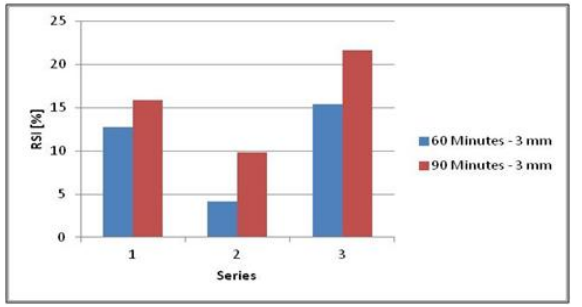

(a)

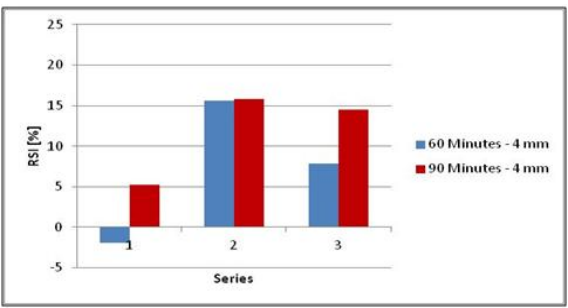

(b)

Fig. 6. RSI of CFDST columns (a) $t_{0}=3 \mathrm{~mm}$; (b) $\mathrm{t}_{0}=4 \mathrm{~mm}$.

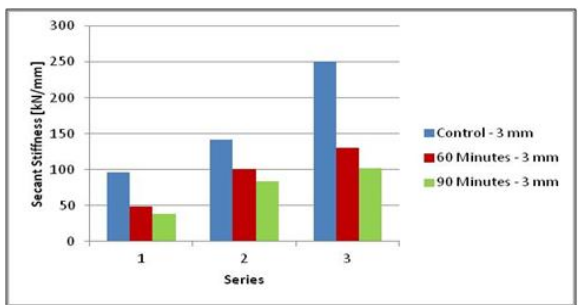

(a)

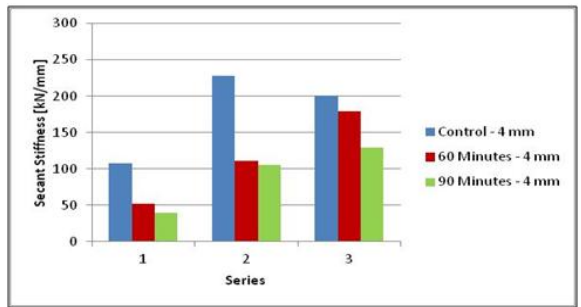

(b)

Fig. 7. Secant stiffness of CFDST columns (a) $\mathrm{t}_{0}=3 \mathrm{~mm}$; (b) $\mathrm{t}_{0}=4 \mathrm{~mm}$.

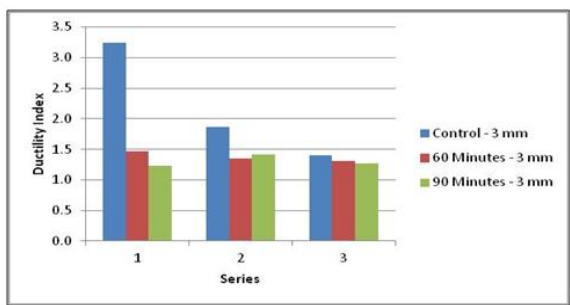

(a)

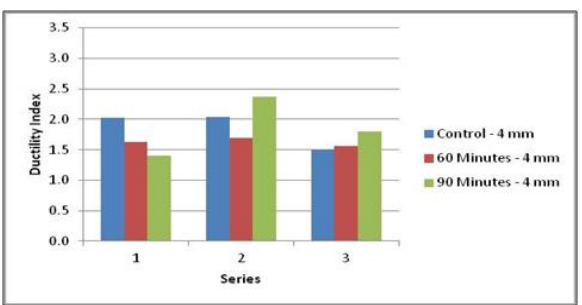

(b)

Fig. 8. DI of CFDST columns (a) $\mathrm{t}_{0}=3 \mathrm{~mm}$; (b) $\mathrm{t}_{0}=4 \mathrm{~mm}$.

\section{Conclusion}

From the above discussion, the following conclusions can be drawn:

1) All specimens failed by outward local buckling of outer steel tube, crushing of concrete and outward and inward local buckling of inner steel tube.

2) Local buckling and crushing of concrete is more severe for specimens with 90 minutes of exposure time compared to specimens with 60 minutes of exposure time.

3) Residual Strength Index, RSI for specimens with 90 minutes of exposure time and $\mathrm{t}_{0}=3 \mathrm{~mm}$ possessed the highest RSI.

4) Secant stiffness of CFDST columns decreased with increased exposure time regardless of $t_{0}$.

5) Ductility Index, DI for Series 2 and Series 3 for specimens with $t_{0}=4 \mathrm{~mm}$ exceeds the original DI. 
Authors are thankful for the financial and technical support provided by Universiti Sains Malaysia (USM) and Universiti Tun Hussein Onn Malaysia (UTHM) Vot.

\section{References}

[1] J. Purkiss, Fire Safety Engineering Design of Structures, ButterworthHeinemann, Jordan Hill, Oxford (1996)

[2] E.U. Chowdhury, Behaviour of Fibre Reinforced Polymer Confined, PhD Thesis, Queen's University, Ontario, Canada, (2009)

[3] J.M. Irwan, S.K. Faisal, N. Othman, M.H. Wan Ibrahim, R.M. Asyraf and M.M.K. Annas, Performance of concrete using light waste PET fibre, Adv. Materials Research, 795, 352-355, (2014)

[4] S. Shahidan, S.S.M. Zuki and N. Jamaluddin, Damage grading system for severity assessment on concrete structure, Case Studies in Constr. Materials, 5, 79-86, (2016)

[5] V.K.R. Kodur, T.T. Lie, Experimental Studies on the Fire Resistance of Circular Hollow Steel Columns Filled with Steel-Fibre-Reinforced Concrete, J. of Fire Protection Engineering, 7, 89-97, (1995)

[6] X. Zhao, R. Grzebieta and M. Elchalakani, Tests of concrete-filled double skin CHS composite stub columns, Steel Comp Struct: Int. J., 2, 129-146, (2002)

[7] L.H. Han, Y. F. Yang and L. Xu, An experimental study and calculation on the fire resistance of concrete-filled SHS and RHS columns, J. Constr. Steel Res., 59, 427-452, (2003)

[8] S. Shahidan, I. Isham, and N. Jamaluddin, A Review on Waste Minimization by Adopting in Self Compacting Concrete, MATEC Web of Conf., 47, 1-7, (2016)

[9] J. Ding, Y.C. Wang, Realistic modelling of thermal and structural behaviour of unprotected concrete filled tubular columns in fire, J. Constr. Steel Res., 64, 1086-1102, (2008)

[10] L.H. Han, W. Li and R. Bjorhovde, Developments and advanced applications of concrete-filled steel tubular (CFST) structures: Members, J. Constr. Steel Res., 100, 211-228, (2014)

[11] S. Shahidan, H.B. Koh, A.M.S. Alansi, and L. Y. Loon, Strength Development and Water Permeability of Engineered Biomass Aggregate Pervious Concrete, MATEC Web of Conf., 47, 1-6, (2016)

[12] X.L. Zhao and R. Grzebieta, Strength and ductility of concrete filled double skin (SHS inner and SHS outer) tubes, Thin-Walled Struct., 40, 199-213, (2002)

[13] R. Imani, M. Bruneau and G. Mosqueda, Simplified analytical solution for axial load capacity of concrete-filled double-skin tube (CFDST) columns subjected to fire, Engineering Structure, 102, 156-175, (2015)

[14] H. Lu, X.L. Zhao and L.H. Han, FE modelling and fire resistance design of concrete filled double skin tubular columns, J. Constr. Steel Res., 67, 17331748, (2011)

[15] H. Lu, L.H. Han and X.L. Zhao, Fire performance of self-consolidating concrete filled double skin steel tubular columns: Experiments, Fire Safety J., 45, 106-115, (2010) 
[16] H. Lu, X.L. Zhao and L.H. Han, Testing of self-consolidating concrete-filled double skin tubular stub columns exposed to fire, J. Constr. Steel Res., 66, 1069-1080, (2010)

[17] H. Yang, L.H. Han, Y.C. Wang, Effects of heating and loading histories on post-fire cooling behaviour of concrete-filled steel tubular columns, J. Constr. Steel Res., 64, 556-570, (2008)

[18] Y.Yang and L.Han, Fire Resistance of Concrete-Filled Double Skin Steel Tubular Columns, Proc. of the 4th Int.l Conf. on Adv. in Steel Struc. Shanghai, China, 1047-1052, (2005)

[19] L. Han, Y. Yang, H.Yang and J. Huo, Residual strength of concrete-filled RHS columns after exposure to the ISO-834 standard fire, Thin-Walled Struct., 40, 991-1012, (2002)

[20] BSEN 12390-3, Testing hardened concrete-Part 3: Compressive strength of test specimens, British Standards, London, United Kingdom, (2009)

[21] ASTM E8/E8M-11, Standard Test Methods for Tension Testing of Metallic Materials, West Conshohocken, PA, (2011)

[22] ASTM E119-11, Standard Test Methods for Fire Tests of Building Construction and Materials, West Conshohocken, PA, (2010)

[23] N. Short, J. Purkiss, S. Guise, Assessment of fire damaged concrete using colour image analysis, Constr. Build. Mater., 15, 9-15, (2001)

[24] S.S.M. Zuki, K.K. Choong, J. Jayaprakash and S. Shahidan, Behavior of Fire Exposed Concrete-Filled Double Skin Steel Tubular ( CFDST ) Columns under Concentric Axial Loads, Appl. Mech. Mater, 773-774, 938-42, (2015)

[25] S.S.M. Zuki, K.K. Choong, J. Jayaprakash, S. Shahidan, Effect of Diameter on Fire Exposed Concrete-Filled Double Skin Steel Tubular (CFDST) Columns under Concentric Axial Loads, Appl. Mech. Mater., 802, 130-135, (2015)

[26] S. Shahidan, S.S.M. Zuki, K.K. Choong, J. Jayaprakash, Repaired of FireDamaged Concrete-Filled Double Skin Steel Tubular (CFDST) Columns With Fiber Reinforced Polymer (FRP), ARPN J. Eng. Appl. Sci., 11, 3718-372, (2016)

[27] L. Han and J. Huo, Concrete-Filled Hollow Structural Steel Columns after Exposure to ISO-834 Fire Standard, J. Struct. Eng., 129, 68-78, (2003)

[28] S.Gunalan, M. Mahendran, Structures Experimental investigation of post-fire mechanical properties of cold-formed steels, Thin Walled Struct.,84, 241-254, (2014)

[29] M.B. Dwaikat, Flexural Response Of Reinforced Concrete Beams Exposed To Fire, PhD Thesis, Michigan State University, (2009)

[30] X. Qiang, F.S.K. Bijlaard and H. Kolstein, Deterioration of mechanical properties of high strength structural steel S460N under steady state fire condition, Mater. Des., 36, 438-442, (2012)

[31] F. Liu, L. Gardner, H. Yang, Post-fire behaviour of reinforced concrete stub columns confined by circular steel tubes, J. Constr. Steel Res, 102, 82-103, (2014)

[32] Z. Tao, L.H. Han, J.P. Zhuang, Cyclic performance of fire-damaged concretefilled steel tubular beam-columns repaired with CFRP wraps, J. Constr. Steel Res., 64, 37-50, (2008)

[33] Z. Tao, L.H. Han, Behaviour of fire-exposed concrete-filled steel tubular beam columns repaired with CFRP wraps, Thin-Walled Struct.,45, 63-76, (2007) 